\title{
STUDENT READINESS HIGH SCHOOL ENTRANCE EXAMS HIGHER EDUCATION AND THE ROLE OF SCHOOL COUNSELORS
}

Tri Anjar

Program Studi Bimbingan dan Konseling UM Metro

\begin{abstract}
The process of preparing to take the test SNMPTN is something that often makes prospective students experiencing various problems. I prepare for the selection of the necessary physical, material, and also psychological. This research was initiated from the problems that occurred in the preparation of the admission public universities by students coming from private schools. These problems such as high school rules violations / lack of discipline, learn less motivated to learn. This condition greatly affects the readiness of students to achieve success SNMPTN pass. This study aimed to describe the readiness of high school students college entrance exams and the role of BK teacher / school counselor. The study population is students of SMA Muhammadiyah 1 Metro are 212 students. This type of research is quantitative descriptive, and the questionnaire used as an instrument of collecting data. The results showed that the average score of 80.53 with an average percentage of $26.84 \%$, are in the category is not ready. BK teacher's role in preparing students in private schools that help students related to school by making a counseling program, either individually or in the classical style. Increase cooperation with fellow teachers and parents and guardians to fostering the development of children's potential.
\end{abstract}

Keyword: Readiness, Students, Counselor role

\section{PENDAHULUAN}

Seleksi Nasional Masuk

Perguruan Tinggi Negeri (SNMPTN) jalur tertulis merupakan ajang paling kompetitif dan penuh tantangan bagi para siswa lulusan SMA sederajatdi seluruh Indonesia.

Berdasarkan Permendiknas No. 34 tahun 2010 tentang Pola Penerimaan Mahasiswa Baru Program Sarjana pada Perguruan Tinggi yang diselenggarakan oleh pemerintah, melalui pola seleksi secara nasional dilakukan seluruh perguruan tinggi secara besama untuk diikuti calon mahasiswa seluruh indonesia. Dengan demikian SNMPTN (Seleksi Nasional Masuk Perguruan Tinggi Negeri) merupakan ajang paling kompetitif bagi siswa lulusan SMA di seluruh indonesia. Berdasarkan pengalaman Praktik lapangan Bimbingan Konseling tahun 2010 di salah satu sekolah swasta dan obeservasi dibeberapa sekolah di kota Metro, salah satunya adalah SMA Muhammadiyah 1 Kota Metro. Fenomena di lapangan menunjukkan bahwa di antara sekolahsekolah SMA swasta, lebih banyak 
permasalahan yang dialalmi siswa bila dibandingakan sekolah negeri. Permasalahan yang dialami siswa bukan saja pada pembelajaran, namun juga menyangkut kehidupan secara pribadi, seperti tingginya pelanggaran tata tertib sekolah/kurang disiplin, belajar kurang termotivasi. Sulit berkonsentrasi ketika mengikuti pelajaran di kelas karena kelelahan membantu orangtua, sering mengantuk ketika belajar sedang berlangsung, sehingga kurang memperhatikan pelajaran yang di sampaikan guru. Kemudian ada juga siswa yang mengobrol dengan kawan duduknya/main hand phone saat pembelajaran berlangsung, sehingga materi pelajaran kurang dikuasai.

Selain itu beberapa siswa secara bergantian sering izin keluar kelas ketika pembelajaran berlangsung hanya untuk merokok di kamar kecil/menyelinap dibelakang kelas, ada juga yang pergi ke kantin sekolah. Halhal seperti itu juga sangat besar pengaruhnya terhadap proses dan hasil belajar siswa, mengakibatkan ketidaksiapan siswa sambil dalam belajar untuk menghadapi ujian masuk perguruan tinggi. Di samping itu ketidaksiapan siswa memasuki perguruan tinggi dipengaruhi masalah ekonomi keluarga. Banyak di antara siswa sambil sekolah turut membantu bekerja orangtua mencari nafkah keluarga, sehingga banyakwaktu belajar tersita yang disebabkan kurangnya kemampuan siswa dalam mengatur waktu belajar. Bagi siswa yang orangtuanya tidak mampu secara ekonomi, maka berpengaruh terhadap sarana dan prasarana belajar siswa yang minim/seadanya. Pada akhirnya mempengaruhi penguasaan materi dan keterampilan belajar, maka banyak siswa tidak cukup memiliki keberanian dan/kepercayaan dari berkompetisi pada ujian masuk perguruan tinggi negeri jalur tertulis dan khawatir tidak diterima di perguruan tinggi tersebut.

Hal itu tentu tidak bisa dibiarkan belangsung terus menerus, namun harus ada upaya dari berbagai pihak terkait dan terpadu untuk dapat mengatasi permasalahan tersebut, agar siswa dapat meningkatkan disiplin dan kualitas pemebelajarannya sehingga dapat meningkatkan kesiapan untuk mengikuti ujian masukperguruan tinggi.

Kesiapan adalah salah satu faktor penentu keberhasilan mengikuti ujian masuk dan diterima diperguruan tinggi. Hamalik (2003) mengemukakan "kesiapan adalah keadaan kapasitas yang ada pada diri siswa dalam hubungan dengan tujuan pengajaran tertentu". Dari pendapat tersebut mengandung arti bahwa kesiapan itu 
tergantung pada diri pribadi siswa yakni mencakup fisik, psikologis, dan hal lain yang mendukung dan terkait pembelajaran untuk dapat dikembangkan dan diupayakan dengan berbagai cara agar dapat mencapai tujuan yang diinginkan. Adapun faktorfaktor kesiapan menurut Slameto (2010) yaitu, kondisi kesiapan mencakup tiga hal, yaitu: (1)

kondisi fisik, mental dan emosional, (2) kebutuhan-kebutuhan, motif dan tujuan,

(3) keterampilan, pengetahuan dan pengertian yang lain yang telah dipelajari.

Senada dengan pendapat sebelumnya yang diungkapkan oleh Darsono (2000) bahwa faktor kesiapan meliputi; (a) kondisi fisik yang tidak kondusif, seperti: sakit, pasti akan memepengaruhi kesiapan siswa dalam menghadapi ujian, (b) kondisi psikologis yang kurang baik, seperti gelisah, tertekan, dan sebagainya. Hal ini tidak menguntungkan dan menghambat kesiapan siswa untuk menghadapi ujian. Kemudian Djamarah (2002) menyatakan bahwa faktor-faktor kesiapan meliputi (a) kesiapan fisik yakni selalu berusaha menjaga kesehatan tubuh agar selalu sehat, bugar dan fit (terhindar dari gangguan sakit, lesu, mengantuk, dan sebagainya), (b) kesiapan psikis yakni berusaha menjaga suasana hati dan/atau emosi agar merasa senang, tenang dan tidak stress, sehingga ada hasrat untuk belajar, dapat berkonsetrasi, dan ada motivasi intrinsic, (c) kesiapan materiil yakni adanya bahan yang bisa dipelajarai atau dikerjakan berupa buku bacaan, catatan, soal-soal dll, sebagai latihan dan menambah wawasan, sehingga dapat membantu kesiapan siswa untuk mengikuti ujian yang dimaksud.

Menilik beberapa pendapat di atas, maka dapat diambil kesimpulan bahwa kesiapan adalah keseluruhan kondisi fisik dan psikologis siswa untuk membentuk sikap dangancara tertentu sehingga individu mempunyai keinginan bertindak untuk melakukan suatu upaya dalam mempersiapkan dirinya sampai kondisi diri siap.

Brunner (1963) mengatakan"readiness for learning" dapat dipengaruhi oleh beberapa hal yaitu;

Intelecktualdevelopment (perkembangan intelektual), b) The act of learning (tindakan dalam belajar), c) Spiral curriculum introduce earlier (tindakan memperkenalkan kurikulum spriral lebih awal).

Slameto (2003) mengemukakan ada dua faktor yang mempengaruhi keberhasilan siswa dalam belajar yaitu faktor intern 
yang terdiri dari faktor jasmaniah (kesehatan, cacat tubuh), faktor psikologis (inteligensi, perhatian, minat, bakat motif, kematangan dan kesiapan, serta keterampilan belajar), faktor kelelahan ( jasmani dan rohani). Sedangkan faktor ektern seperti, lingkungan keluarga, sekolah dan masyarakat.

Djamarah (2008:) bahwa kesiapan sumber belajar yakni adanya bahan yang bisa dipelajari atau dekerjakan berupa buku bacaan, catatan, soal-soal dll, sehingga dapat membantu kesiapan siswa untuk mengikuti ujian yang dimaksud.

Dengan demikian diharapkan siswa memiliki keterampilan belajar khususnya dalam mengerjakan soal-soal ujian sejenis dengan soal SNMPTN, sehingga siswa lebih memiliki kesiapan untuk mengikuti ujian SNMPTN tertulis dan berhasil diterima di PTN. Kemudian tidak kalah pentingnya adalah pengulangan pelajaran dan penguasaan meteri pelajaran.

Secara umum penelitian ini bertujuan untuk mendeskripsikan kesiapan siswa SMA mengikuti ujian masuk perguruan tinggi dan peran guru BK/Konselor sekolah.

\section{METODE PENELITIAN}

Penelitian ini merupakan penelitian kuantitatif dengan metode deskriptif. Menurut Lehmann (dalam Yusuf, 2005) penelitian deskriptif yaitu "penelitian yang mendeskripsikan secara sistematis, aktual dan akurat mengenai fakta-fakta dan sifat populasi tertentu, atau mencoba menggambarkan fenomena secara detail". Penelitian ini akan mendeskripsikan tentang kesiapan siswa SMA mengikuti ujian masuk perguruan tinggi dan peran guru BK/Konselor sekolah yang akan terungkap dari hasil pengolahan instrumen yang diberikan. Adapun subyek dalam penelitian ini adalah seluruh guru BK/Konselor sekolah pada SMA Muhammadiyah 1 Kota Metro, berjumlah 3 orang dan siswa kelas XII berjumlah 212 orang yang terdaftar pada tahun ajaran 2011/2012, dengan menggunakan purposive sampling.

Penelitian ini mendeskripsikan tingkat kesiapan siswa mengikuti ujian masuk perguruan tinggi (PT) dan peran guru $\mathrm{BK} /$ Konselor sekolah. Adapun teknik pengumpulan data untuk mengukur tingkat kesiapan siswa mengikuti ujian masuk perguruan tinggi menggunakan angket tertutup model skala Likert. Data yang telah terkumpul dianalisis dengan menggunakan rumus persentase : 


$$
\mathrm{P}=\frac{f}{n} x 100
$$

Keterangan :

$\mathrm{P}=$ Tingkat persentase jawaban

$\mathrm{f}=$ Frekuensi jawaban

$\mathrm{n}=$ Jumlah sampel (A. Muri Yusuf, 2005)

Sedangkan untuk mendeskripsikan peran guru BK/Konselor sekolah dalam memebantu siswa memepersiapkan diri mengikuti ujian masuk perguruan tinggi dengan wawancara. Data hasil wawancara dianalisis dengan cara naratif, maksudnya jawaban yang diperoleh dari pertanyaan yang diajukan akan dideskripsikan dan selanjutnya ditarik kesimpulan.

Uji validasi instrumen dilakukan dengan rumus korelasi Pearson Product Moment dan uji reabilitas instrumen dengan teknik Alpha Cronbach menggunakan program SPSS versi 18.0 diperoleh nilai Alpha Cronbach variabel kesiapan siswa adalah 0,713 dengan tingkat kepercayaan $95 \%$.

Selanjutnya untuk melihat tingkat capaian responden pada variabel kesiapan siswa digunakan Mean hypothetic atau kreterium Strurgess (dalam Mangkuatmodjo, 1997:37).

Tabel 1. Kategori Skala Kesiapan

\begin{tabular}{|l|l|}
\hline Rentangan & Keterangan \\
\hline ST $=\geq$ St-I & Sangat Siap \\
\hline $\mathbf{T}=$ St-2.I s.d. St-I & Siap \\
\hline
\end{tabular}

\begin{tabular}{|l|l|}
\hline SD $=$ St-3.1 s.d.St-2.I & Cukup Siap \\
\hline RD $=$ St-4.I s.d. St- 3.I & Kurang Siap \\
\hline SR $=\leq$ St - 4.I & Tidak Siap \\
\hline
\end{tabular}

\section{HASIL}

Hasil analisis dapat dilihat pada tabel berikut :

Tabel 2. Deskripsi Kesiapan Siswa mengikuti Ujian Masuk PT.

\begin{tabular}{|c|c|c|c|c|c|}
\hline \multirow[t]{2}{*}{ No } & \multirow[b]{2}{*}{$\begin{array}{c}\text { Sub } \\
\text { Variabel }\end{array}$} & \multicolumn{4}{|c|}{ Skor } \\
\hline & & Jum & $\begin{array}{r}\text { Rata- } \\
\text { rata }\end{array}$ & $\begin{array}{c}\% \\
\text { Rata- } \\
\text { rata }\end{array}$ & Kategori \\
\hline 1 & $\begin{array}{l}\text { Kesiapan } \\
\text { diri } \\
\text { pribadi }\end{array}$ & 4455 & 80.75 & 26.92 & $\begin{array}{r}\text { Tidak } \\
\text { siap }\end{array}$ \\
\hline 2 & $\begin{array}{l}\text { Kesiapan } \\
\text { dalam } \\
\text { belajar }\end{array}$ & 3604 & 75.69 & 25.23 & $\begin{array}{r}\text { Tidak } \\
\text { siap }\end{array}$ \\
\hline 3 & $\begin{array}{l}\text { Kesiapan } \\
\text { informasi } \\
\text { PT }\end{array}$ & 848 & 85.14 & 28.38 & $\begin{array}{l}\text { pangat } \\
\text { siap }\end{array}$ \\
\hline \multicolumn{2}{|c|}{$\begin{array}{l}\text { Keseluruhan } \\
(42)\end{array}$} & 8907 & 80.53 & 26.84 & \begin{tabular}{|r} 
Tidak \\
Siap \\
\end{tabular} \\
\hline
\end{tabular}

Tabel 3. Kesiapan Fisik dan Psikologis Siswa

\begin{tabular}{|l|l|l|l|l|l|}
\hline No & & \multicolumn{3}{|c|}{ Skor } \\
\cline { 2 - 6 } & Indikator & Jum & $\begin{array}{c}\text { Rata- } \\
\text { rata }\end{array}$ & $\begin{array}{c}\text { \% } \\
\text { Rata- } \\
\text { rata }\end{array}$ & Kategori \\
\hline 1 & $\begin{array}{l}\text { Menjaga } \\
\text { Kesehatan }\end{array}$ & $\mathbf{4 7 7 6}$ & $\mathbf{1 5 9 . 2}$ & $\mathbf{1 2 . 5 2}$ & Tidak siap \\
\hline 2 & $\begin{array}{l}\text { Pengaturan } \\
\text { Waktu } \\
\text { istirahat \& } \\
\text { rekreasi }\end{array}$ & $\mathbf{2 2 6 7}$ & $\mathbf{1 5 1 . 1 3}$ & $\mathbf{2 3 . 7 6}$ & Tisak siap \\
\hline 3 & $\begin{array}{l}\text { Pengaturan } \\
\text { waktu } \\
\text { istirahat } \\
\text { \&rekreasi }\end{array}$ & $\mathbf{2 4 8 7}$ & $\mathbf{1 6 5 . 8}$ & $\mathbf{2 6 . 0 7}$ & $\begin{array}{l}\text { Kurang } \\
\text { siap }\end{array}$ \\
\hline 4 & $\begin{array}{l}\text { Motivasi } \\
\text { Belajar }\end{array}$ & $\mathbf{1 5 5 8}$ & $\mathbf{1 5 5 . 8}$ & $\mathbf{3 6 . 7 5}$ & $\begin{array}{l}\text { Cukup } \\
\text { Siap }\end{array}$ \\
\hline 5 & $\begin{array}{l}\text { Motivasi } \\
\text { Belajar }\end{array}$ & $\mathbf{2 8 8 3}$ & $\mathbf{1 4 4 . 2}$ & $\mathbf{1 7 . 0 0}$ & Tidak siap \\
\hline 6 & $\begin{array}{l}\text { Aspek } \\
\text { mental } \\
\text { apiritual }\end{array}$ & $\mathbf{2 3 6 3}$ & $\mathbf{1 5 9 . 5}$ & $\mathbf{2 5 . 0 7}$ & $\begin{array}{l}\text { Kurang } \\
\text { siap }\end{array}$ \\
\hline $\begin{array}{l}\text { Keseluruhan } \\
\mathbf{2 1})\end{array}$ & $\mathbf{1 6 3 6 3}$ & $\mathbf{1 5 5 . 8}$ & $\mathbf{3 . 5 0}$ & Tidak siap \\
\hline
\end{tabular}

Tabel 4. Kesiapan belajar Siswa

\begin{tabular}{|c|c|c|c|c|c|}
\hline No & & \multicolumn{4}{|c|}{ Skor } \\
\cline { 3 - 6 } & Indikator & Jum & $\begin{array}{c}\text { Rata- } \\
\text { rata }\end{array}$ & $\begin{array}{c}\text { \% } \\
\text { Rata- } \\
\text { rata }\end{array}$ & Rategori \\
\hline 1 & $\begin{array}{c}\text { Ketermpilan } \\
\text { Belajar }\end{array}$ & $\mathbf{4 7 7 6}$ & $\mathbf{1 5 9 . 2}$ & $\mathbf{1 2 . 5 2}$ & $\begin{array}{c}\text { Tidak } \\
\text { siap }\end{array}$ \\
\hline
\end{tabular}




\begin{tabular}{|c|c|c|c|c|c|}
\hline 2 & $\begin{array}{l}\text { enguasaan } \\
\text { meteri } \\
\text { pelajaran }\end{array}$ & 1983 & 132.2 & 20.79 & $\begin{array}{r}\text { Tidak } \\
\text { siap }\end{array}$ \\
\hline 3 & $\begin{array}{l}\text { engulangan } \\
\text { meteri } \\
\text { pelajaran }\end{array}$ & 1702 & 165.8 & 26.07 & $\begin{array}{c}\text { Kurang } \\
\text { siap }\end{array}$ \\
\hline 4 & $\begin{array}{l}\text { Pengaturan } \\
\text { waktu } \\
\text { belajar }\end{array}$ & 3372 & 155.8 & 36.75 & $\begin{array}{l}\text { Cukup } \\
\text { Siap }\end{array}$ \\
\hline 5 & $\begin{array}{l}\text { Kelengkap } \\
\text { an catatan }\end{array}$ & 966 & 144.2 & 17 & $\begin{array}{c}\text { Tidak } \\
\text { siap }\end{array}$ \\
\hline 6 & $\begin{array}{l}\text { emehaman } \\
\text { teknis } \\
\text { mengerjak } \\
\text { an soal } \\
\text { ujian }\end{array}$ & 2407 & 160.5 & 25.23 & $\begin{array}{c}\text { Kurang } \\
\text { siap }\end{array}$ \\
\hline \multicolumn{2}{|c|}{$\begin{array}{l}\text { Keseluruhan } \\
\text { (17) }\end{array}$} & 12579 & 148.16 & 25.26 & $\begin{array}{l}\text { Kurang } \\
\text { siap }\end{array}$ \\
\hline
\end{tabular}

Hasil analisis menunjukkan bahwa capaian tingkat kesiapan belajar siswa untuk mengikuti ujian masuk perguruan tinggi berada pada katergori kurang siap.

Tabel 5. Kesiapan informasi PT

\begin{tabular}{|c|c|c|c|c|c|}
\hline No & \multirow{2}{*}{ Indikator } & \multicolumn{3}{|c|}{ Skor } \\
\cline { 2 - 6 } & Jum & $\begin{array}{c}\text { Rata- } \\
\text { rata }\end{array}$ & $\begin{array}{c}\text { \% } \\
\text { Rata- } \\
\text { rata }\end{array}$ & $\begin{array}{l}\text { Kategor } \\
\text { i }\end{array}$ \\
\hline 1 & $\begin{array}{l}\text { Kelengakapan } \\
\text { informasi } \\
\text { PT }\end{array}$ & $\mathbf{1 6 8 8}$ & $\mathbf{1 6 8 . 8}$ & $\mathbf{3 9 . 8 1}$ & $\begin{array}{l}\text { Sangat } \\
\text { siap }\end{array}$ \\
\hline 2 & $\begin{array}{l}\text { Ketegasan } \\
\text { arah } \\
\text { jurusan } \\
\text { yang } \\
\text { diinginkan }\end{array}$ & $\mathbf{1 5 8 8}$ & $\mathbf{1 5 8 . 8}$ & $\mathbf{3 7 . 5}$ & $\begin{array}{l}\text { Sangat } \\
\text { siap }\end{array}$ \\
\hline $\begin{array}{l}\text { Keseluruhan } \\
\mathbf{( 4 )}\end{array}$ & $\mathbf{1 6 3 6 3}$ & $\mathbf{1 5 5 . 8}$ & $\mathbf{3 5 . 0}$ & $\begin{array}{l}\text { Sangat } \\
\text { siap }\end{array}$ \\
\hline
\end{tabular}

Hasil analisis menunjukkan bahwa capaian tingkat kesiapan siswa tentang informasi untuk mengikuti ujian masuk PT berada pada kategori sangat siap.

\section{PEMBAHASAN}

Kesiapan siswa ditinjau dari diri pribadi, dalam balajar dan segi informasi untuk mengikuti ujian masuk PT melalui jalur SNMPTN tertulis. Berikut dijelaskan pembahasan untuk masing-masing sub variabel yang dikaji dalam penelitian ini.

\section{Kesiapan Siswa mengikuti ujian Masuk PT}

Berdasarkan hasil analisis data, secara umum skor rata-rata sebesar 80.53 dengan persentase rata-rata sebesar $26,84 \%$, berada pada ketegori tidak siap. Dengan demikian dapat dikemukakan bahwa berdasarkan hasil temuan penelitian, sebagai besar siswa belum memiliki kesiapan yang memadai. Hal itu disebabkan oleh karena siswa dalam pengaturan waktu istirahat dan rekreasi masih rendah, motivasi belajar masih sangat rendah dan kelengkapan catatan siswa sangat rendah. Hal itu tentunya tidak bisa diabaikan bagitu saja, namun semestinya menjadi perhatian khusus bagi kepala sekolah, guru mata pelajaran, guru BK/Konselor sekolah dan orang tua murid.

Untuk membantu siswa yang mengalami kesulitan dalam belajar perlu diupayakan pengajaran perbaikan, kegiatan belajar, pengembangan sikap dan kegiatan belajar yang efektif (Prayitno \& Erman Amti, 2004)

Berkaitan dengan peningkatan motivasi belajar siswa, dapat dilakukan dengan menempuh prosedur menurut Abu Ahmadi \& Widodo Supriono (dalam Ahmad, 2011) sebagai berikut : 
(1) Meningkatkan dorongan kepada siswa untuk belajar

(2) Emnjelaskan secara kongkrit kepada siswa apa yang dapat dilakukannya setelah akhir program pengejaran

(3) Meciptakan suasana belajar yang menantang, merangsang dan menyenangkan

(4) Memberikan penguatan dan ganjaran terhadap prestasi yang dicapai

(5) Menciptakan hubungan yang hangat dan dinamis antara guru dengan siswa dan antara siswa dengan siswa.

(6) Menghindari tekanan yang tidak menentu, seperti suasana menakutkan, menjengkelkan dan mengecewakan

(7) Melengkapi sumber dan peralatan belajar

Dari pendapat tersebuat dapat dimaknai bahwa masalah kesulitan belajar dapat diatasi dengan perbaikan dan penigkatan pembelajaran oleh si pembelajar, guru mata pelajaran dan bersama guru BK/Konselor sekolah. Dalam hal ini guru BK/ Konselor sekolah dapat membantu siswa melalui layanan misalnya, layanan penguasaan konten, seperti (cara membuat catatan yang baik, pemberian tips cara belajar yang efektif, dll) bisa juga dengan layanan informasi dan bimbingan kelompok topik tugas, seperti (sikap belajar yang baik, meningkatkan motivasi belajar, keuntungan belajar kelompok), bisa juga dengan konseling perorangan dan konseling kelompok.
Dengan demikian diharapkan seluruh siswa memiliki tingkat kesiapan yang memadai sehingga siap untuk berkompetisi dalam ujian masuk perguruan tinggi melalui jalur SNMPTN tertulis.

\section{Kesiapan fisik dan psikologis siswa}

Berdasarkan hasil analisis data yang dilakukan menunjukan bahwa capaian tinbgkat kesiapan fisik dan psikologis siswa untuk mengikuti ujian masuk PT berada kategori tidak siap.

Hal ini ditunjukkan dengan capaian persentasi siswa yang rata-rata berada pada kategori kurang siap dan tidak siap. Berdasarkan pada temuan penelitian, maka guru BK/konselor sekolah dapat memberikan berbagai bimbingan dan layanan dalam membantu meningkatkan kesehatan siswa seperti: layanan informasi yang terkait dengan menjaga kesehatan (pola hidup sehat, tips menjaga kebugaran tubuh). Dalam hal ini guru BK/ Konselor sekolah juga perlu berkerjasama dengan orang tua siswa, agar memperhatikan asupan gizinya atau nutrisi sehingga tubuh siswa terjaga kesehatanya.

Apabila kesehatan individual terjaga secara baik, maka individual tersebut dengan kemampuan fisiknya 
dapat berdaya guna baik pribadi maupun sosial dalam kehidupan. Kesiapan fisik merupakan salah satu kondisi yang sangat menentukan hasil dari setiap aktifitas, baik dalam pembelajaran, bekerja dan lain-lain, terutama dalam segi kesehatan.

Faktor-faktor fisiologis yang berhubungan dengan belajar adalah keadaan jasmani atau nutrisi yang dikonsumsi siswa. Kebutuhan gizi harus diperhatikan oleh orang tua untuk menunjang keberhasilan belajar siswa. Selain itu kesehatan merupakan faktor penting dalam belajar, bila kondisi siswa kurang sehat apalagi mengidap penyakit kronis akan mempengaruhi kehadiranya dan ini akan mempengaruhi penguasaanya terhadap materi pelajaran. Maka kesehatan fisik perlu dijaga dan diperhatikan.

Terkait dengan hal tersebut Prayitno (2002) mengungkapkan bahwa untuk menjaga kesehatan dan kesegaran fisik, ada beberapa hal yang perlu diperhatikan yaitu : 1) biasakan tidur secara cukup sebelum mengikuti proses belajar mengajar esok harinya, 2) usahakan makan makanan yang bergizi setiap harinya,3) biasakan melakukan oleh raga yang teratur,4) hindari merokok, minuman beralkohol, dan sejenisnya.
Ada 7 kebiasan hidup sehat yang perlu dilakukan untuk memelihara kesehatan dan kekuatan fisik, yakni sarapan pagi, makan secara teratur, makan secukupnya untuk menjaga berat badan yang normal, tidak meroko, tidak minum yang mengandung alkohol, olah raga secara teratur, dan tidur secara teratur (Mulyani, 2007:5). Pendapat tersebut dapat dimaknai bahwa jika tubuh sehat maka kita senantiasa siap untuk melakukan aktifitas apapun tanpa ada gangguan yang disebabkan oleh kondisi fisik. Hal itu dapat terwujud apabila siswa mempersiapkan tubuh/fisik secara baik dengan menjaga kesehatan, sehingga semua organ tubuhnya dapat berfungsi secara optimal dalam mengerjakan soal ujian.

Selain kondisi fisik yang sehat, maka kondisi psikologis sama pentingnya untuk persiapan dalam mengikuti ujian masuk PT. Dari hasil temuan ini menunjukkan bahwa masih ada sejumlah siswa belum memiliki kesiapan psikologis yang memadai khususnya dari segi emosi maupun motivasi belajarnya untuk mengikuti ujian masuk perguruan tinggi. Motivasi merupakan salah satu unsur penting untuk meraih suatu tujuan.

Motivasi adalah suatu perubahan seseorang yang ditandai dengan timbulnya afektif (perasaan) dan reaksi 
untuk mencapai tujuan. Seperti Djamarah (2006) mengatakan motivasi merupakan gejala psikologis dalam bentuk dorongan yang timbul pada diri seseorang sadar atau tidak sadar untuk melakukan suatu tindakan dengan tujuan tertentu. Oleh sebab itu motivasi mempunyai peranan yang amat penting dalam segala aktivitas, termasuk belajar. Jika tidak ada motivasi belajar, berarti tidak ada kegiatan belajar karena tidak ada aktifitas tanpa motivasi.

Pada indikator motivasi belajar dan emosi, guru BK/Konselor sekolah dapat melakukan bimbingan pribadi dan bimbingan belajar kepada siswa serta bimbingan kelompok, konseling kelompok dan konseling individual. Selain guru bidang studi juga diharapkan mampu memberikan dorongan kepada siswa untuk memberikan otoritasnya dalam membangun gagasan, tanggung jawab belajar yang kondusif tanpa adanya tekanan dan mendorong motivasi siswa untuk belajar, sehingga siswa semakin terbantu dan lebih memiliki kesiapan secara psikologis.

Oleh sebab itu kesiapan psikis siswa/calon mahasiswa untuk mengikuti ujian masuk PTN juga perlu dipersiapkan dengan baik, yakni dengan menjaga agar kondisi psikis sehat yang ditandai dengan kemandirian siswa dalam menangani masalah keseharian dengan mencerminkan sikap yang positif.

\section{Kesiapan Belajar Siswa}

Berdasarkan hasil analisis data yang dilakukan menunjukkan bahwa persentase pencapaian tingkat kesiapan belajar siswa kurang siap. Hal itu disebabkan masih rendahnya keterampilan belajar siswa, penguasaan materi pelajaran sangat rendah, selain itu kelengkapan catatan siswa masih kurang lengkap serta pemahaman teknis mengerjakan soal ujian masih rendah. Hal ini perlu mendapat perhatian dari guru mata pelajaran dan guru BK/Konselor sekolah.

Agar siswa berada dalam kondisi siap dalam belajar untuk menghadapi ujian, menurut Sumadi Suryabrata (dalam Ahmad, 2011) ada beberapa hal yang perludi lakukan agar siswa siap menghadapi ujian, yakni :

penjadwalan waktu belajar,

mempelajari kembali, (3) menyiapkan perlengkapan ujian. Artinya perlengkapan sekecil apapun merupakan hal yang mendukung kesuksesan dalam menempuh ujian.

Dengan demikian dapat disimpulkan bahwa kondisi siap atau tidaknya seseorang untuk menghadapi 
ujian, salah satunya ditentukan oleh penguasaan materi pelajaran/ujian.

Selain itu penguasaan materi pelajaran dan ketermpilan belajar sisiwa, perlu ditingkatkan agar siswa lebih banyak menguasai materi pelajaran dan juga mempunyai banyak keterampilan dalam belajar.

Berdasarkan pendapat di atas dapat disimpulkan bahwa kesiapan dalam belajar adalah bagaimana siswa tersebut dapat mengoptimalkan belajarnya dengan mengupayakan berbagai cara, sebagai bentuk persiapan untuk memasuki perguruan tinggi, baik dari segi pengaturan waktu belajar, keterampilan belajar, kelengkapan catatan dan bahan belajar yang diperlukan. Dengan demikian diharapkan siswa lebih siap berkompetisi mengikuti ujian masuk PT jalur tertulis.

\section{Kesiapan Informasi tentang Perguruan Tinggi}

Dari hasil analisisi data yang dilakukan menunjukkanbahwa persentase pencapaian tingkajt kesiapan siswa berkenaan dengan informasi perguruan tinggi secara keseluruhan berada pada kategori sangat siap. Artinya sebagian besar siswa telah memiliki kesiapan yang memadai berkenan dengan informasi perguruan tinggi. Hasil penelitian ditemukan pada indikator ketegasan arah jurusan yaitu $2,99 \%$ dan $2,91 \%$ siswa belum bisa/masih bingung dalam menentukan jurusan apa yang akan dipilih jika mengikuti ujian masuk perguruan tinggi nanti, karena kurangnya informasi. Oleh sebab itu guru BK/Konselor sekolah perlu memberikan layanan informasi yang lebih lengkap, seperti ; informasi tentang sekolah lanjutan, macam-macam perguruan tinggi dan jurusan, persyaratan pendaftaran dan penerimaan, informasi karir, jenis perkerjaan).

Dalam hal itu juga diharapkan kerjasama pihak sekolah dengan perguruan tinggi, agar informasi lebih mudah diakses dan lebih lengkap didapat siswa. Khulthau (1991) menyoroti aspek afektif dalam proses pencarian informasi. Dalam modelnya, Kulthau menggambarkan kegiatan pencarian informasi sebagai sebuah proses konstruksi (pengembangan, pembangunan) yang dilalui seseorang dari tahap ketidak-pastian (uncertainty) menuju pemahaman (understanding). Ada 6 tingkatan atau langkah yang terkandung dalam proses konstruksi ini, yaitu : awalan (initiation), pemilihan (selection), penjelajahan (exploration), penyusunan (formulation), pengumpulan (collection), dan penyajian(presentation). 
Dari pendapat tersebut menyiratkan bahwajika seseorang mencari informasi hendaklah melalui langkah-langkah dan proses yang benar, sehingga orang itu memperoleh informasi yang akurat dan lengkap, maka diharapkan siswa bisa memahami dan mencari informasi seperti model diatas, kemudian dapat menyajikan dalam bentuk kesiapan yang optimal.

Dari uraian di atas dapat disimpulkan bahwa capaian tingkat kesiapan siswa tentang informasi berada pada kategori sangat siap untuk mengikuti ujian masuk perguruan tinggi melalui jalur SNMPTN tertulis.

\section{Peran guru BK/Konselor sekolah dalam membantu siswa untuk persiapan mengikuti ujian masuk PT}

Berdasarkan hasil temuan penelitian membuktikan bahwa peran guru BK/Konselor sekolah belum optimal. Hal ini ditunjukkan dengan adanya perlakuan yang sama oleh guru BK dalam penanganan masalah siswa, yang sebenarnya tidak dibenarkan oleh profesi. Seperti yang diungkapkan oleh Prayitno (2004) tidak ada suatu carapun yang ampuh untuk semua klien dan semua masalah. Bahkan masalah yang samapun pemecahannya perlu dibedakan. Masalah yang kelihatannya "sama" setelah dikaji secara mendalam mungkin ternyata hakekatnya berbeda, sehingga diperlukan cara yang berbeda menanganinya. Lebih lanjut Prayitno (2004) mengatakan, pada dasarnya, pemakaian suatu cara tergantung pada pribadi siswa, jenis dan sifat masalah, tujuan yang ingin dicapai, kemampuan guru BK dan sarana yang tersedia. Dengan demikian, tidaklah mungkin memberikan pelayanan yang sama tehadap siswa yang memiliki perbedaan satu sama lain.

Selain itu guru BK masih menganjar mata pelajaran tertentu pada beberapa kelas, sehingga waktu yang seharusnya digunakan untuk memberikan layanan konseling, tersita untuk mengajar. Kemudian guru BK juga terkesan dalam melaksanakan tugas pokok dan fungsinya lebih memilih jalan mudah dan praktis, terlihat dari pengambilan keputusan yang begitu mudah untukmengembalikan siswa kepada orang tua wali, tanpa terlebih dahulu mendalami permasalahan yang sebenarnya terjadi pada siswa itu. Hal ini tentunya tidak bisa dibenarkan dan dibiarkan karena dapat merugikan siswa untuk memperoleh haknya dan dapat menciderai profesi konseling. 
Oleh karenanya sekolah sebagai salah satu lembaga pendidikan membutuhkan pelayanan Bimbingan dan Konseling oleh guru BK/Konselor sekolah yang memenuhi kualifikasi sesuai dengan Permendiknas No. 27 tahun 2008 tentang standar Kualifikasi Akademik dan Kompetensi Konselor, pasal 1 ayat 1 , menyebutkan bahwa untuk dapat diangkat sebagai konselor, seseorang wajib memenuhi standar kualifikasi akademik dan kompetensi konselor yang berlaku secara nasional serta menguasai triologi profesi konselor.

Bimbingan dan konseling adalah salah satu unsur yang amat penting dari sistem pendidikan disekolah. Oleh karenanya keberadaan guru BK/Konselor sekolah seharusnya bisa menjadi motor penggerak untuk kemajuan pendidikan di sekolah. Dengan demikian maka guru BK harus bisa melaksanankan tugas pokok dan fungsinya sebagai konselor sekolah, sehingga dapat berperan aktif dalam membantu mengoptimalkan potensi siswa melalui berbagai layanan konseling.

Tugas dan peran guru BK/ Konselor sekolah menurut Yusuf (2006) yaitu; 1) memahami konsep-konsep bimbingan dan konseling, serta ilmu bantu lainnya, 2) memahami karakteristik pribadi siswa, khususnya tugas-tugas perkembangan siswa faktorfaktor yang mem pengaruhi, 3) merumuskan perencanaan program layanan BK, 4)mensosialisasikan program layanan BK, 5) melaksanakan program layanan BK, yaitu dasar bimbingan layanan responsive, layanan perencanaan individual dan layanan dukungan sistem, 6) mengevaluasi program hasil (perubahan sikap dan perilaku siswa, baik dalam aspek pribadi, sosial, belajar dan karir), 7) menindaklanjuti (follow up) hasil evaluasi, 8) menjadi guru dan konselor bagi guru dan orang tua siswa, 9) bekerjasama dengan pihak-pihak lain yang terkait, 10) mengadministrasikan program layanan bimbingan, 11) menampilkan pribadi secara matang, baik menyangkut aspek emosional, sosial, maupun moral spiritual, 12) memiliki kemampuan dan kemauan untuk senantiasa mengembangkan model layanan bimbingan seiring dengan kebutuhan dan masalah siswa, 13) mempertanggungjawabkan tugas kegiatan kepada kepala sekolah.

Berdasarkan pendapat di atas seorang guru BK/Konselor sekolah harus menguasai dan memahami dasar konsep BK, karakteristik siswa dan berbagai layanan, maka guru BK/Konselor sekolah dapat 
mengoptimalkan pemberian layanan yang disesuaikan kebutuhan siswa. Dengan demikian diharapkan siswa dapat berkembang potensinya, sehingga siswa memiliki gambaran tentang arah masa depannya, tahu apa yang harus dilakukan dan dapat menentukan arah masa depannya sendiri sesuai pilihannya, termasuk pilihan untuk mengikuti ujian masuk perguruan tinggi melalui jalur SNMPTN tertulis.

\section{SIMPULAN}

Berdasarkan pembahasan hasil penelitian yang telah di lakukan dapat di kemukakan sebagai berikut :

1. Capaian tingkat kesiapan siswa dari segi (diri pribadi, dalam belajar dan informasi) untuk mengikuti ujian masuk perguruan tinggi berada pada kategori tidak siap.

2. Capaian tingkat kesiapan dari segi pribadi (fisik dan psikikologis siswa) untuk mengikuti ujian masuk perguruan melalui jalur SNMPTN tertulis, berada pada kategori tidak siap.

3. Capaian tingkat kesiapan siswa dalam belajar untuk mengikuti ujian masuk perguruan tinggi melalui jalur SNMPTN tertulis, berada pada kategori kurang siap.
4. Capaian tingkat kesiapan siswa tentang informasi PT untuk mengikuti ujian masuk perguruan tinggi melalui jalur SNMPTN tertulis, berada pada kategori tidak siap.

5. Peran guru BK//Konselor sekolah dalam membantu siswa untuk mengikuti ujian masuk perguruan tinggi melalui jalur SNMPTN tertulis, belum optimal.

\section{SARAN}

Berdasarkan hasil penelitian, pembahasan, kesimpulan dan implikasi yang telah dikemukakan di atas, ada beberapa saran yang diajukan peneliti, yaitu :

1. Kepada guru BK/Konselor sekolah untuk membantu siswa terkait dengan sekolah lanjutan dengan membuat program bimbingan konseling baik secara individual ataupun secara klasikal. Meningkatkan kerjasama dengan sesama guru dan orang tua wali murid untuk pembinaan dan pengembangan potensi anak.

2. Kepada guru mata pelajaran agar bisa lebih inovatif dan kreatif lagi untuk meningkatkan kualitas pembelajaran di sekolah, sehingga siswa lebih mudah memahami dan menguasai materi pelajaran. 
3. Kepada orang tua wali murid agar punya waktu lebih untuk dapat memperhatikan anak dalam aktifitas belajarnya di rumah, mengingatkan jika ada tugas dari sekolah untuk segera mengerjakannya, sehingga siswa tidak lalai dan jika memungkinkan ekonomi orang tua untuk bisa melengkapi sarana dan prasarana agar belajar lebih baik dan hasil lebih optimal.

4. Peneliti selanjutnya, direkomendasikan untuk memperluas dan mengem bangkan variabel yang diteliti sekarang.

\section{DAFTAR PUSTAKA}

Ahmad, Riska. 2011. "Model Penyiapan Siswa Menghadapi Ujian Akhir".(Studi pada Siswa Kelas III di SMA Padang). (Disertasi).Tidak dipublikasikan.

Brunner, Jerome S. 1963. The Process of Education. Vintage Books. New York.

Darsono, dkk, 2000. Belajar dan Pembelajaran. Semarang : IKIP Semarang Press.

Djamarah, Syaiful Bahri. 2002, Rahasia Sukses Belajar. Jakarta : Cerdas

Kuhlthau. 1991. Ragam Teori Informas. PusatDokumentasi dan Informasi Ilmiah.(http://episentrum.com) diakses 12 Januari 2015).
Mangkuatmojo, Soegiyarto.1997. Dasar-dasar Statistik. Jakarta: Angkasa

Hamalik, Oemar. 2009. Psikologi Belajar. Membantu Guru dalam Perencanaan, Pengajaran, Penilaian Perilaku dan Memberi Kemudahan kepada Siswa dalam Belajar. Bandung : Sinar Baru Agensindo.

Permendiknas No 34 tahun 2010

Prayitno.1997. Seri Pemandu Pelaksanaan Bimbingan dan Konseling di SMU (SPPBK). Jakarta : Depdiknas.

--------, 2002. Seri Keterampilan Belajar (Program Semi Que IV). Padang : Depdiknas.

Prayitno dan Erman Amti. 2004. Dasardasar Bimbingan dan Konseling. Jakarta : Rineka Cipta.

Slameto. 2003. Belajar dan faktor-fator yang mempengaruhinya. Jakarta : Rineka Cipta.

Yusuf, A. Muri. 2005. Evaluasi Pendidikan; Dasar-dasar dan Teknik. Padang: UNP Press.

Yusuf, Syamsu. 2006. Psikologi Perkembangan Anak dan Remaja. Bandung : PT. Remaja Rosda Karya.

Winkel dan Sri H. 2004. Bimbingan dan Konseling di Institusi Pendidikan. Yogyakarta: Media Abadi. 